\title{
A boka-kar index oszcillometriás elven múködő meghatározásának helye a klinikai gyakorlatban
}

\author{
Járai Zoltán dr. ${ }^{1,5}$ - Kolossváry Endre dr. ${ }^{2}$ - Szabó Ildikó dr. ${ }^{2}$ \\ Kiss István dr. ${ }^{3}$ - Farsang Csaba dr. ${ }^{4}$. Farkas Katalin dr. ${ }^{2,5}$ \\ Szent Imre Egyetemi Oktató Kórház, ${ }^{1}$ Kardiológia Profil, ${ }^{2}$ Angiológia Profil, ${ }^{3}$ Nefrológia Profil, \\ ${ }^{4}$ Anyagcsere Központ, ${ }^{5}$ Angiológiai Tanszéki Csoport, Budapest
}

\begin{abstract}
Bevezetés: A boka-kar index meghatározása során az oszcillometriás eszközök a hagyományos Doppler-elven múködő eszközökkel összevetve több ígéretes előnyt mutatnak. A speciális képzés szükségtelensége, a gyorsabb kivitelezés, valamint a mérés operátortól független volta sorolható ezek közé.

Célkitüzés: A boka-kar index oszcillometriás és a Doppler-elven múködő meghatározásának összehasonlító elemzése. Módszer: A vizsgálati egyének esetében folyamatos hullámú Doppler és automata oszcillometriás (BOSO ABI-system 100) módszerrel a boka-kar index egyidejú meghatározását végeztük. Az összehasonlító elemzés Bland-Altman- és ROC-analízis alkalmazásával történt.

Eredmények: A két módszerrel végzett vizsgálat (734 mérés) jó egyezést mutatott a boka-kar index tartomány 0,9 értékéhez közel. Ezen érték alatt és felett az egyezés mértéke csökkent. Az oszcillometriás mérés során optimálisnak tekinthető diagnosztikus boka-kar index határérték 0,96 volt.

Köpetkeztetések: A boka-kar index oszcillometriás meghatározása nem helyettesíti a Doppler-alapú mérést a teljes boka-kar index tartományban. Mindazonáltal a hatékony diszkriminációs tulajdonságának köszönhetően a tünetmentes egyének szürésekor hathatós eszköz lehet.
\end{abstract}

Orv Hetil. 2018; 159(5): 176-182.

Kulcsszavak: boka-kar index, Doppler-módszer, oszcillometriás módszer, perifériás érbetegség

The potential role of oscillometric devices for ankle-brachial index measurements in clinical practice

Introduction: Oscillometric devices in contrast to the traditional Doppler based method for ankle-brachial index measurements have promising advantages like no need for special training, faster performance, and operator independence.

Aim: Comparative assessment of the oscillometric and Doppler-based ankle-brachial index measurement.

Method: Ankle-brachial index measurements were performed by continuous wave Doppler and an automatic oscillometric device (BOSO ABI-system 100) in consecutive subjects. The comparative assessment was performed by Bland-Altman and ROC analysis.

Results: The two kinds of measurements (734 measurements) showed a good agreement in the ankle-brachial index spectrum close to the cut-off value of 0.9 . The agreement diminished below or above this value. The optimal oscillometric ankle-brachial index diagnostic cut-off value was 0.96 .

Conclusions: The oscillometric device is not interchangeable for Doppler devices in the whole ankle-brachial index spectrum. Nevertheless, owing to its discriminative power, the oscillometric measurement potentially has an efficient role in the screening of asymptomatic patients.

Keywords: ankle-brachial index, Doppler method, oscillometric method, peripheral arterial disease

Járai Z, Kolossváry E, Szabó I, Kiss I, Farsang Cs, Farkas K. [The potential role of oscillometric devices for anklebrachial index measurements in clinical practice]. Orv Hetil. 2018; 159(5): 176-182.

(Beérkezett: 2017. október 8.; elfogadva: 2017. november 9.) 


\section{Rövidítések}

$\mathrm{BKI}=$ boka-kar index CW Doppler $=($ continuous wave Doppler) folyamatos hullámú Doppler

Az atherosclerosis alsó végtagi megjelenési formájának, a perifériás verőérszúküuletnek a gyakorisága növekedést mutat a világon [1]. Tekintettel arra, hogy az alsó végtagi keringészavar klinikai megjelenésében széles spektrumot mutat, a tünetmentes esetek számaránya jelentősen meghaladja a típusos tüneteket mutató betegekét - a tünetek rögzítése mellett objektív módszer szükséges a kórállapot hatékony felismeréséhez. Ebben az értelemben a boka-kar index (BKI) meghatározása széles körben ajánlott vizsgálóeljárás [2]. A módszerrel végzett magyarországi, tudományos közlés formájában ismertetett szűrővizsgálatok 50 éves kor feletti hypertoniás populációban a perifériás érbetegség gyakoriságát 14,4\%-nak [3], hasonló életkorú általános népességben végzett szürôvizsgálatban, a Budakalász Vizsgálatban pedig 16,1\%nak találták [4].

$\mathrm{Az}$ alsó végtagi verőérszúküulet diagnosztikájában használatos BKI-mérés módszerét bemutató első közlemény 1950-ben jelent meg [5]. Azóta a módszer alkalmazásával kapcsolatban ismereteink jelentősen bővültek. A vizsgálat elvégzésének indikációját képezi az atherosclerosis alsó végtagra vonatkozó következményeinek felismerése és követése. Ezáltal lehetôség nyílik az alsó végtagi érszúküulet progressziójának becslésére, az ér átjárhatóságának helyreállítását célzó endovascularis vagy érsebészeti mütét szükségességének megállapítására, valamint a beavatkozás eredményességének megítélésére. $\mathrm{Az}$ alsó végtagi atherosclerosis diagnosztikája mellett az epidemiológiai adatok alapján a BKI meghatározásának szerepe van az egész szervezetet érintő cardiovascularis rizikó becslésében is. Az ezzel a módszerrel kimutatott érszúkület szoros összefüggést mutat a más érterületi (agyi keringés, coronariakeringés) klinikai események és az ezzel összefüggő halálozás alakulásával [6]. A hagyományos, atherosclerosis-kockázatot becslő módszerek hatékonyságát a BKI-meghatározás eredménye javítja [7-9].

A BKI meghatározásának klasszikus módja az adott érszakaszon, a folyamatos hullámú (continuous wave, CW) Doppler-elv alapján történő szisztolés vérnyomás mérésén alapszik. A nemzetközi ajánlások pontosan meghatározzák azokat a szempontokat, eljárási módokat, amelyek biztosítják a BKI-eredmények megbízhatóságát. A vizsgálat kivitelezésének körülményei, a végtagi nyomás mérésére használatos mandzsetták paraméterei, a kiválasztott érszakaszok, ahol a mérések történnek (arteria brachialis, arteria dorsalis pedis, arteria tibialis posterior), a mérések elvégzésének sorrendje, az index számításának módja azok a tényezők, amelyek döntően meghatározzák az eredmények megbízhatóságát [8].

A Doppler-elven történő BKI-meghatározás diagnosztikus hatékonyságát különböző képalkotó eljárások eredményeivel vetették össze. Ezen összehasonlítások adatai szerint a Doppler-módszer szenzitivitása 0,171,0 , specificitása $0,8-1,0$ volt. Az alacsonyabb szenzitivitás diabetes mellitus együttes jelenléte esetén volt jellemző. ROC-analízisek adatai szerint a diagnosztikus hatékonyságot jelző „c” statisztika értéke 0,87-0,95 között volt, ami a módszer megfelelő hatékonyságát mutatja [8]. A Doppler-elven történő BKI-meghatározás során diagnosztikus határértéknek hagyományosan a 0,9 értéket tekintik. Ezen értéket, illetve ez alatti BKI-értéktartományt tekintik a perifériás érszúkület meghatározójának. A különböző ROC-analíziseken alapuló tanulmányok eredményei azt mutatják, hogy ezt az értéket nem lehet „kőbevésett” értéknek tekinteni. Az optimális határértéket befolyásolja a betegség adott populációban való előfordulása, a populáció klinikai jellemzői, kísérő betegségek jelenléte, valamint a BKI-mérés módszere. Vélhetően a 0,91-1,0 BKI-tartományt érdemes átmeneti tartománynak tekinteni, ahol az értékek interpretációját a perifériás érbetegség preteszt valószínűsége befolyásolja [8].

A Doppler-elven történő BKI-meghatározás az előbbiekben bemutatott tulajdonságok figyelembevételével a meghatározó klinikai ajánlások részévé vált $[7,10,11]$.

Miközben a módszer széles körü (háziorvosi praxisok, angiológiai, érsebészeti ellátóhelyek, sürgősségi ambulanciák) alkalmazása ajánlott, kérdés, hogy a módszer milyen mértékben elfogadott, illetve alkalmazott ebben a körben. Az Amerikai Egyesült Államokban egy nagy, perifériás verőérbetegség felismerését célul tűző epidemiológiai vizsgálat (PARTNERS) folytatásaként a BKImódszer alkalmazását elemezték. Több mint 3000 háziorvosi praxisba küldték el azokat a kérdőíveket, amelyek alapján a BKI alkalmazását kívánták vizsgálni. A háziorvosok 24-38\%-a mutatott hajlandóságot a kérdőív kitöltésére. Ezen motiváltnak gondolható praxisokban a dolgozók közel 70\%-a soha nem alkalmazta a BKI-meghatározást a gyakorlatban. Megkérdezték a vizsgálatban részt vevőket, hogy mi az oka a módszer csekély mértékben történő alkalmazásának. A válaszok a gyakoriság sorrendjében a rendelkezésre álló idő (56\%), a finanszírozás (45\%), valamint a mérést végző dolgozó (45\%) hiányát jelölték meg döntően. Emellett felvetették a képzettségben való hiányosságot, a betegek elzárkózását, a klinikai jelentőség megkérdőjelezését, valamint a fizikai hely hiányát [12]. Ilyen jellegű magyar adatsor nem áll rendelkezésre, azonban vélhető a hasonló vagy még rosszabb eredmény.

A tudományosan megalapozott ajánlások és a hétköznapi gyakorlat közötti távolság közelítésének lehetséges eszköze - a felvilágosításon túl - a vizsgálati módszerek fejlesztése. Az elmúlt években a hagyományos Dopplerelven történő BKI-meghatározás mellett új, oszcillometriás elven múködő készülékek elterjedése látható [13, 14]. Az oszcillometriás módszert alkalmazó BKI-mérőeszközök nyilvánvaló előnye lehet a négy végtagon történő egyidejü vérnyomásmérés miatt a szükséges mérési 
1. táblázat |A vizsgálatban részt vevők klinikai jellemzői

\begin{tabular}{ll}
\hline Betegszám & 397 \\
Nő/férfi (\%) & $55,4 / 44,6$ \\
Életkor (év) & $63,9 \pm 11,5$ \\
Dohányzás (\%) & 24,1 \\
Perifériás érbetegség az anamnézisben (\%) & 26,5 \\
Diabetes mellitus (\%) & 27,6 \\
Doppler-BKI & $0,969 \pm 0,25$ \\
Oszcillometriás (BOSO) BKI & $0,92 \pm 0,3$ \\
Perifériás érbetegség Doppler-BKI alapján (\%) & 26 \\
\hline
\end{tabular}

$\mathrm{BKI}=$ boka-kar index

idő csökkenése, valamint a mérési eredmények változékonyságának mérséklése. Mindezek az előnyök az alapellátásban történő alkalmazást segíthetik [14].

Vizsgálatunk célja a hagyományos Doppler-elven alapuló BKI-meghatározás és egy új, oszcillometriás elven történő mérési módszer összehasonlítása volt.

\section{Módszer}

A Magyar Hypertonia Társaság ÉRV Regiszter Programjában részt vevő nyolc központban történt a betegek bevonása. Az alap klinikai jellemzők rögzítését követően minden beteg esetében elvégeztük a hagyományos Doppler és az oszcillometriás BKI-meghatározást. A két mérést ugyanaz a személy végezte. Egy 20 főból álló alcsoportban ellenőriztük az oszcillometriás módszer megismételhetőségét, valamint a két módszer időigényét. A folyamatos hullámú Doppler-vizsgálatokat a validált ELITE 200 Doppler $/ 5 \mathrm{MHz}$ eszközzel, az oszcillometriás méréseket a BOSO müszerrel (BOSO ABI-system 100, Bosch+Sohn $\mathrm{GmbH}$ and Co. KG, Jungingen, Germany) végeztük el.

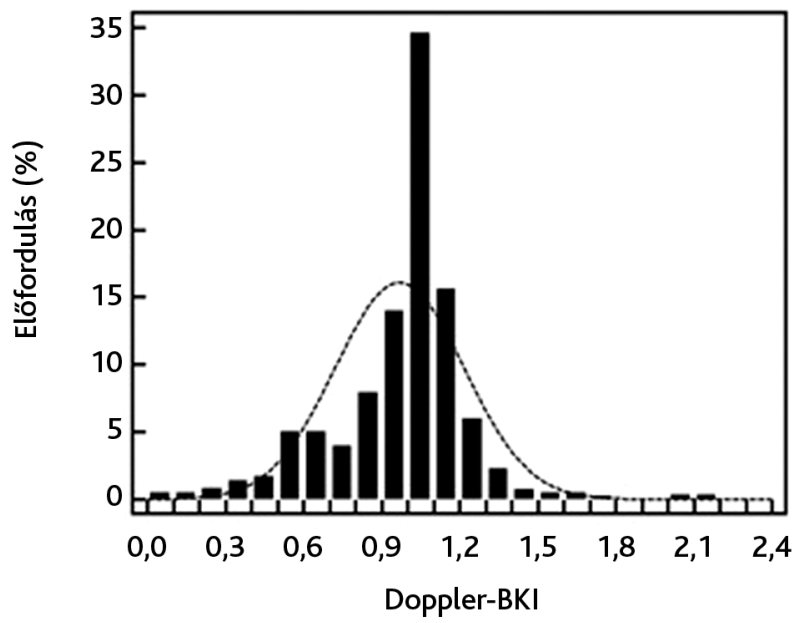

A két módszer eredményei közötti kapcsolatot regressziós analízissel vizsgáltuk. Az eljárások helyettesíthetőségét Bland-Altman-analízissel, a diagnosztikus hatékonyságot ROC-analízissel elemeztük. A két módszer időigényét Wilcoxon-teszttel hasonlítottuk össze. A statisztikai próbákat MedCalc for Windows (12.3.1.0, Mariakerke, Belgium) számítógépes programmal végeztük el. Az összehasonlító vizsgálat kezdeményezője a Magyar Hypertonia Társaság volt.

\section{Eredmények}

A vizsgálatba összesen 397 beteget vontunk be. A bevont személyek klinikai jellemzőit az 1. táblázatban tüntettük fel. A két módszer alkalmazása során összesen 793 mérés összehasonlítását végeztük el (egy beteg esetén korábbi amputáció miatt csak egy végtag adatai kerültek rögzítésre).

Egy húsz fóből álló alcsoportban ellenőriztük az oszcillometriás módszer megismételhetőségét. Az eredmények standard deviációja 0,0683 , a variációs koefficiens 6,53\%, az interclass korreláció 0,8462 (0,7481-0,9139) volt. A két módszer kivitelezéséhez szükséges idő szignifikáns mértékben különbözött (Doppler: 5,7 $\pm 0,64$ perc vs. oszcillometriás módszer: $2,1 \pm 0,37$ perc).

A két módszer BKI-értékeinek eloszlását az 1 a ábrán tüntettükfel. A Doppler-módszer esetén az értékek normál eloszlást mutatnak, az oszcillometriás módszer esetén az eredmények többsége hasonló mintázatot mutat, azonban elkülönülten felismerhető egy alcsoport, amelyben az oszcillometriás BKI-vizsgálat nulla értéket mutat. Ez utóbbi eredmény az összes mérés 7,6\%-ában (61 eset) fordult elő. A 61 esetből összesen két esetben volt a Doppler-vizsgálat eredménye hasonlóan nulla. A fennmaradó 59 esetet úgy tekintettük, hogy az oszcillometriás eredmény nem értékelhető, és ezeket a méréseket a további analízisből kizártuk. Többváltozós logisztikus regressziós vizsgálat alapján a nem értékelhető oszcillo-

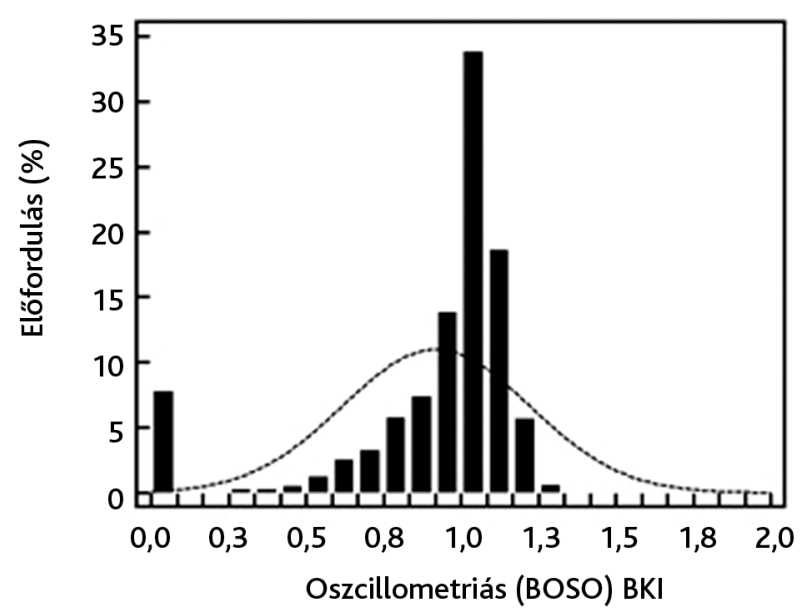


metriás eredmények meghatározója az alacsony Doppler-érték volt (esélyhányados 25 [5,3-118]).

A további összehasonlítást 734 mérési eredmény felhasználásával végeztük el. A két módszer BKI-értékei között regressziós analízissel szignifikáns kapcsolatot találtunk $(\mathrm{r}=0,689, \mathrm{p}<0,01)$, azonban megjegyzendő, hogy a korrelációs együttható négyzete, a determinációs együttható 0,475 volt. A két módszer közötti konkordanciát leíró kappa statisztika 0,7 volt. A két módszer egyezését, illetve helyettesíthetőségét Bland-Altmananalízissel elemeztük. Az analízis eredményét a 2. ábrán tüntettük fel. A két módszer által meghatározott BKIértékek eltérése átlagosan 0,0115 volt, a megegyezési határ $( \pm 2$ SD) 0,32 és $-0,29$ közé esett. A mért BKI-tartományban a két módszer eredményeinek különbsége lineáris összefüggést mutatott.

Az oszcillometriás módszer diagnosztikus hatékonyságát ROC-analízissel elemeztük. Az eredményeket a 3. ábrán tüntettük fel. A ROC-modellben a hagyományos Doppler-módszert tekintettük referenciaként. A „c" statisztika (AUC) értéke 0,935 volt. Az oszcillometriás módszer szenzitivitása $76,8 \%$, specificitása $93,6 \%$ volt a $\mathrm{BKI} \leq 0,9$ határértéket alapul véve. A vizsgált populációban a perifériás érszúkület előfordulását $(26 \%)$ figyelembe véve, az oszcillometriás módszer pozitív prediktív értéke $66,3(57,1-77,4)$, negatív prediktív értéke 96,1 $(94,3-97,5)$ volt. A Youden-index alapján kalkulált, optimálisnak tekinthető diagnosztikus BKI-határérték 0,96 volt.

\section{Megbeszélés}

Magyarországon az alsó végtagi verőérszúküulet hatékony felismerésének fontosságát támogatja a nemzetközi összehasonlításban igen magas, érbetegséggel összefüggő amputációk aránya [15]. Az alapellátás túlterheltsége, valamint a BKI meghatározását megvalósító új eszközök terjedése időszerúvé teszi ezen technológia értékének elemzését.

Az új, oszcillometriás elven múködő BKI-meghatározás a könnyebb kivitelezhetőség, rövidebb vizsgálati idő, alacsonyabb mérési variabilitás okán lehetséges és vonzó alternatívája a hagyományos Doppler-elven történő BKImeghatározásnak. A világpiacon több, különböző cég által gyártott készülék jelent már meg, amelyek egy része bizonyítottan validált a BKI meghatározására $[13,14]$. A két mérési módszer mindazonáltal különbözik, így vizsgálandó, hogy az eljárások minden szempontból helyettesíthetők-e.

Tanulmányunkban a Bosch+Sohn $\mathrm{GmbH}$ and Co. KG cég által gyártott, validált mérőmúszerrel kapott mérési eredményeket hasonlítottuk össze a hagyományos Doppler-eljáráson alapuló méréssel. A vizsgálatba bevont egyének nagy száma részletes statisztikai elemzést tett lehetôvé. Az alcsoportvizsgálat alapján az oszcillometriás eljárás megismételhetősége megfelelő, a vizsgálat időigénye jelentősen rövidebb a Doppler-vizsgálattal összeha-

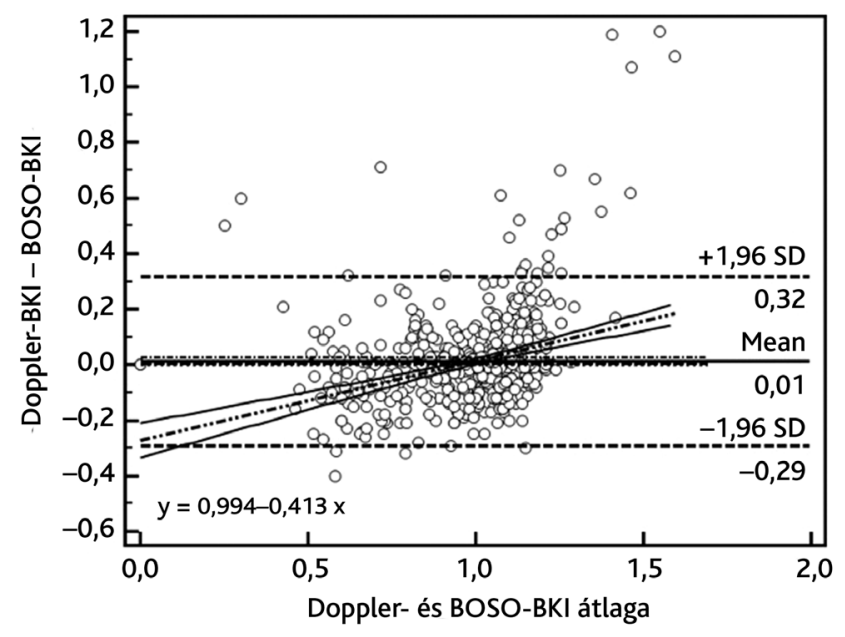

\begin{tabular}{l|l} 
2. ábra & A Doppler-alapú és az oszcillometriás boka-kar index (BKI)-
\end{tabular} eredmények Bland-Altman-analízise

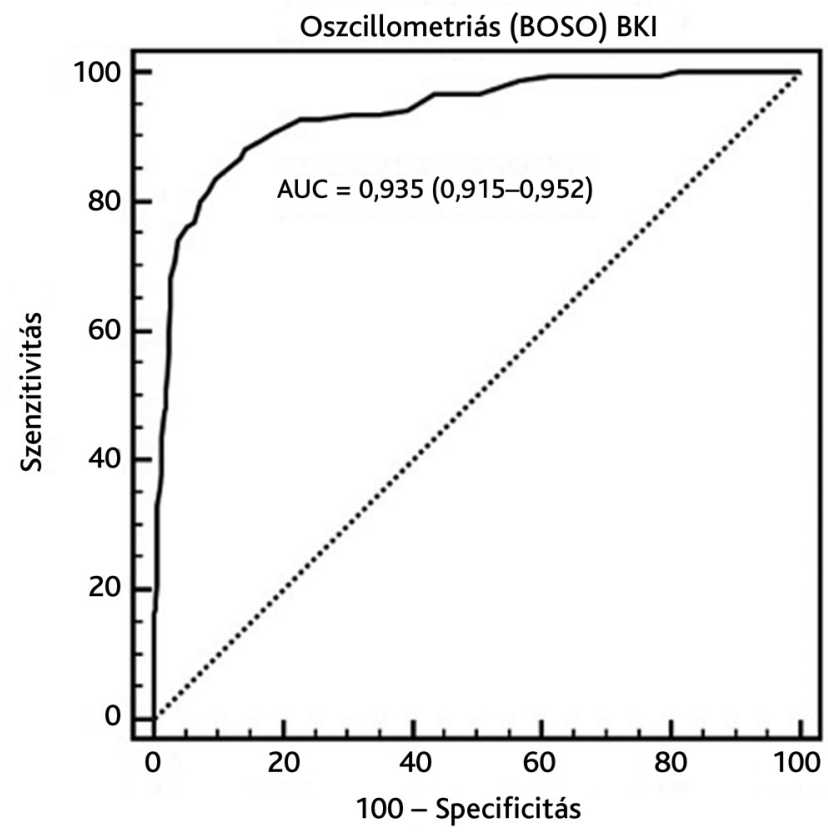

3. ábra $\quad \mathrm{Az}$ oszcillometriás módszer diagnosztikus hatékonyságának ROC-analízise (BKI $\leq 0,9$, referencia: Doppler-módszer)

sonlítva. A mérések 7,4\%-ában az oszcillometriás módszer nem értékelhető eredményt mutatott (nulla érték), amikor a hagyományos módszer eredménye nullától különbözött. A jelenség ismert a szakirodalomban, az általunk tapasztalt gyakoriság nagyságrendjében konzisztens más munkacsoportok közlésével [16-18]. Többváltozós analízisünk alapján a jelenség azzal függhet össze, hogy az oszcillometriás módszer az alacsonyabb BKI-tartományban bizonytalan. Ezzel a véleménnyel összecsengően az irodalomban fellelhető vélemény alapján a nem értékelhető mérések gyakoribbak a hagyományos Doppler-eljárással kórosnak ítélt BKI-tartományban [17]. Felhívják a figyelmet a cukorbetegségre jellemző érfali kalcifikáció lehetséges magyarázó szerepére is [19]. Nem 
egységes az álláspont azzal kapcsolatban, hogy ezeket az eseteket hogyan kell értékelni. Az egyik megközelítés szerint ezek a mérési eredmények alsó végtagi verőérszükület ekvivalensnek tekintendők [18]. Más vélemény szerint a helyes interpretáció az, hogy értékelhetetlennek ítéljük őket és az összehasonlító elemzésekből ki kell zárni azokat [16]. Elemzésünkben az utóbbi módszert követtük azért, hogy az oszcillometriás és Dopplermódszer összehasonlításakor a megegyezés mértékét pontosabban tudjuk megbecsülni. Mindazonáltal a klinikai gyakorlat számára azt javasoljuk, hogy ilyen esetekben hagyományos folyamatos hullámú Doppler-készülékkel ellenőrző mérés történjék.

A további statisztikai elemzésünk alapján a két módszer eredményei között bár szignifikáns kapcsolat áll fenn (regressziós analízis), de a determinációs együttható alacsony értéke alapján az oszcillometriás módszerrel mért BKI-értékek variabilitása csak közel 50\%-ban magyarázható a Doppler-BKI-értékek variabilitásával. Fontos hangsúlyozni, hogy két mérési módszer összehasonlításában a regressziós analízis, mint módszer nem játszik döntő szerepet. A kappa statisztika 0,7 értéke a két módszer közötti jó megfelelésként értékelhető. A két módszer egymással való egyezését, helyettesíthetőségét a Bland-Altman-analízis alapján lehet értékelni [20]. Ennek során a mérési eredmények különbségeit ábrázoljuk a mérési (BKI) tartományban. A mérési eredmények különbségeinek egy kisebb része a megegyezési határon kívülre esett. A definíció szerint $\pm 2 \mathrm{SD}$ értékkel meghatározott megegyezési tartomány igen széles, közel 0,6 BKI-tartományt ölelt fel, amely klinikailag egyértelmúen túl toleránsnak tünik. Az oszcillometriás automata vérnyomásmérók esetén a mérőeszközök validálásával kapcsolatban létezik állásfoglalás arra nézve, hogy mekkora az elfogadható megegyezési tartomány [21]. BKI-mérőeszközök esetén ilyen standard érték eddigiekben nem került meghatározásra. A Bland-Altman-analízis során a két müszer eredményeinek különbsége lineáris összefüggést mutat a mért BKI-tartományban. Ez azt jelenti, hogy az oszcillometriás eljárás a Doppler-módszerrel összehasonlítva a 0,9-1,0 BKI-érték alatt túlbecsüli, e felett pedig alulbecsüli a BKI-értéket, így a két módszer nem tekinthető egymást helyettesíthetőnek a teljes BKItartományban. Mindazonáltal a legszorosabb megfelelés abban a tartományban van (BKI 0,9-1,0), amely a diagnosztikus határpontot tartalmazza. Az oszcillometriás módszer diagnosztikus hatékonyságát ROC-analízissel vizsgáltuk. Referenciaként a hagyományos Dopplermódszert tekintettük. A magas „c" statisztika, ami a ROC-görbe alatti területnek (AUC) felel meg, jó diagnosztikus hatékonyságot jelez. A relatíve magasabb specificitás és a viszonylag alacsonyabb szenzitivitás azt mutatja, hogy a módszer nagy hatékonysággal zárja ki a perifériás veróérbetegség létét annak árán, hogy tévesen pozitív esetek előfordulnak. Ez a tulajdonság a szürővizsgálatok előnyös tulajdonsága. A Youden-index számításának módszere azon alapul, hogy a szenzitivitás és a specificitás egyformán fontos tulajdonság. Grafikai módszerrel megtalálva a legmagasabb szenzitivitás-specificitás párt a ROC-analízis során, meghatározható az ehhez tartozó azon értékhatár (cut off) pont, amely a diagnózis felállításakor ajánlható. Vizsgálatunkban ez 0,96 volt, magasabb, mint a klinikai gyakorlatban, a hagyományos mérésnél alkalmazott 0,9 BKI-határpont. A megfigyelés, miszerint az oszcillometriás módszer esetén vélhetően magasabb határpont az ajánlott a perifériás verőérbetegség diagnózisának felállításakor, a nemzetközi irodalom adataival egyezik. A különböző tanulmányok az oszcillometriás módszer alkalmazása esetén $0,92-1,04$ közé teszik a BKI diagnosztikus határértékét [16, 18, $22]$.

Mielőtt eredményeink alapján megfogalmaznánk az oszcillometriás módszer javasolható helyét a klinikai gyakorlatban, célszerü jelezni vizsgálatunk korlátait. Jelen vizsgálat egy adott oszcillometriás mérőeszköz (BOSO) tulajdonságait vizsgálta. A világpiacon számos hasonló validált - vagy nem validált - eszköz létezik, így eredményeink, következtetéseink nem tekinthetők általános érvényünek az oszcillometriás BKI-mérési eljárással kapcsolatban [13, 14]. Az eredmények általánosíthatóságának korlátja az ún. spektrum-hiba, miszerint egy adott populáción elvégzett vizsgálat eredményei automatikusan nem terjeszthetók ki más tulajdonságokkal jellemezhető populációra [23].

A vizsgálatba általunk bevont egyének nyolc különböző, köztük négy angiológiai központban jelentek meg, ami magyarázza a perifériás verőérbetegség relatíve magas előfordulását. Ugyanezzel az oszcillometriás eszközzel végzett alacsonyabb esetszámú svájci vizsgálat során még magasabb arányban vontak be érszúkületben szenvedő betegeket. Hozzánk hasonlóan a két módszer szolgáltatta eredmény legkevesebb egyezést azokban az esetekben mutatta, amikor előrehaladott érszúküulet volt igazolható [24]. A BKI oszcillometriás módszerrel való szưrésének esetén a javasolt célpopuláció a tünetmentes egyének köre. Míg az általunk vizsgáltak esetén a szélesebb BKI-tartomány segítette az összehasonlítást, addig a tünetmentes egyénekre vonatkozó következtetés lehetősége korlátozott. A jelzett problémát oldhatja, hogy egy cseh munkacsoport szintén ugyanezen eszközzel végzett hasonló nagyságú, de tünetmentes populáción vizsgálatot. A két vizsgálat az összehasonlítás (Doppler vs. BOSO) terén hasonló eredményeket mutatott [25].

\section{Következtetések}

Eredményeink alapján az oszcillometriás módszer jól reprodukálható, a Doppler-eljárással összevetve jóval gyorsabban kivitelezhető, BKI mérésére alkalmas módszer, a következő megjegyzésekkel. Elsősorban a BlandAltman-analízis eredményei alapján a két módszer nem helyettesíti egymást a BKI teljes tartományában. A 0,91,0 BKI-tartomány alatti és feletti eltérés mértéke alapján a módszer nem javasolható olyan klinikai szituációk- 
ban, amikor perifériás verőérbetegség klinikai gyanúja felmerül, vagy az adott klinikai kérdés ismert verőérszükület stádiumának megítélésére vonatkozik (obliterativ érbetegség progressziójának mérése, kritikus végtagi ischaemia felismerése, revascularisatio hatásosságának megítélése, nem komprimálható érpálya kimutatása). Ezen esetekben az arra kijelölt angiológiai, érsebészeti ellátóhelyeken továbbra is a hagyományos Doppler-elven történő vizsgálatok ajánlhatók.

Amennyiben a vizsgálat célja a tünetmentes alsó végtagi verőérszúkület tényének igazolása (kórállapot felismerése, globális cardiovascularis kockázat becslése), elemzésünk alapján az oszcillometriás módszer szűrésként alkalmazva, inkább egy magasabb BKI-határértéket figyelembe véve $(\mathrm{BKI}<1,0)$ jó hatékonyságú lehet.

A szûrés alapvetően az alapellátás feladata, a célpopuláció sokkal nagyobb, mint az előzőekben jelzett alsó végtagi tünetes betegek köre. Ennek megfelelően a családorvosi praxisok tűnnek optimális kivitelezőhelynek, ahol a rendelkezésre álló vizsgálati idő, a Doppler-méréshez szükséges tapasztalat esetleges hiánya miatt az oszcillometriás módszer alkalmazása fejlődést jelenthet az eddigi gyakorlathoz képest. Ezen szürések során az oszcillometriás módszerrel nyert negatív eredmény esetén az ellátó jó eséllyel (magas specificitás) zárta ki az alsó végtagi obliterativ érbetegséget. Ennek a ténynek óriás jelentősége van abban, hogy az alapellátás oldaláról csökkenjen az egészségügyi rendszert sok szempontból terhelő további vizsgálatok kezdeményezése. Amennyiben a szürés során pozitív eredmény születik, vagy a perifériás verőérbetegség klinikai gyanúja fennáll, szükséges a BKI Doppler-módszerrel történő meghatározása. Amennyiben ez a családorvosi praxisban nem kivitelezhető, vagy a Doppler-módszerrel mért BKI kóros értéket mutat, célszerú a beteget szakellátóhelyre utalni a diagnózis igazolása, terápiás javaslat, gondozás kialakítása céljából.

Anyagi támogatás: A közlemény megírása anyagi támogatásban nem részesült.

Szerzői munkamegosztás: J. Z. a kézirat megszövegezésében, K. E. a statisztikai elemzésekben és a kézirat megszövegezésében, Sz. I. az adatbázis létrehozásában és az adatok statisztikai elemzésében, K. I., F. Cs. a kézirat kritikai olvasatában, F. K. a vizsgálati protokoll kidolgozásában és a kézirat kritikai olvasatában vett részt. A cikk végleges változatát valamennyi szerző elolvasta és jóváhagyta.

Érdekeltségek: A szerzőknek nincsenek érdekeltségeik.

\section{Köszönetnyilvánítás}

Köszönet illeti a Bosch+Sohn GmbH and Co. KG céget, aki az oszcillometriás készülékek rendelkezésre bocsátásával segítette a vizsgálatot. Köszönetet mondunk a vizsgálatban részt vevő központok vezetőinek
(Dr. Basista Erika, Dr. Farkas Katalin, Dr. Huberth János, Dr. Landi Anna, Dr. Murányi Anikó, Dr. Poór Ferenc, Dr. Sántha Éva, Dr. Sipos Gyula) a hatékony közremúködésért.

\section{Irodalom}

[1] Fowkes FG, Rudan D, Rudan I, et al. Comparison of global estimates of prevalence and risk factors for peripheral artery disease in 2000 and 2010: a systematic review and analysis. Lancet 2013; 382: 1329-1340.

[2] Fowkes FG, Aboyans V, Fowkes FJ, et al. Peripheral artery disease: epidemiology and global perspectives. Nat Rev Cardiol. 2017; 14: 156-170.

[3] Farkas K, Jarai Z, Kolossvary E, et al. High prevalence of peripheral arterial disease in hypertensive patients: the Evaluation of Ankle-Brachial Index in Hungarian Hypertensives screening program. J Hypertens. 2012; 30: 1526-1532.

[4] Bagyura Z, Kiss L, Édes E, et al. Cardiovascular screening programme in the Central Hungarian region. The Budakalasz Study. [Cardiovascularis szűrőprogram a közép-magyarországi régióban. Budakalász Vizsgálat.] Orv Hetil. 2014; 155: 13441352. [Hungarian]

[5] Winsor T. Influence of arterial disease on the systolic blood pressure gradients of the extremity. Am J Med Sci. 1950; 220: 117126.

[6] Hajibandeh S, Hajibandeh S, Shah S, et al. Prognostic significance of ankle brachial pressure index: A systematic review and meta-analysis. Vascular 2017; 25: 208-224.

[7] Aboyans V, Ricco JB, Bartelink ME, et al. 2017 ESC Guidelines on the Diagnosis and Treatment of Peripheral Arterial Diseases, in collaboration with the European Society for Vascular Surgery (ESVS): Document covering atherosclerotic disease of extracranial carotid and vertebral, mesenteric, renal, upper and lower extremity arteries. Endorsed by: the European Stroke Organization (ESO). The Task Force for the Diagnosis and Treatment of Peripheral Arterial Diseases of the European Society of Cardiology (ESC) and of the European Society for Vascular Surgery (ESVS). Eur Heart J. 2017 Aug 26. doi: 10.1093/eurheartj/ ehx095. [Epub ahead of print]

[8] Aboyans V, Criqui MH, Abraham P, et al. Measurement and interpretation of the ankle-brachial index: a scientific statement from the American Heart Association. Circulation 2012; 126: 2890-2909.

[9] Fowkes FG, Murray GD, Butcher I, et al. Ankle brachial index combined with Framingham Risk Score to predict cardiovascular events and mortality: a meta-analysis. JAMA 2008; 300: 197208.

[10] Gerhard-Herman MD, Gornik HL, Barrett C, et al. 2016 AHA/ ACC Guideline on the Management of Patients With Lower Extremity Peripheral Artery Disease: A Report of the American College of Cardiology/American Heart Association Task Force on Clinical Practice Guidelines. Circulation 2017; 135: e726e779.

[11] Conte MS, Pomposelli FB, Clair DG, et al. Society for Vascular Surgery practice guidelines for atherosclerotic occlusive disease of the lower extremities: management of asymptomatic disease and claudication. J Vasc Surg. 2015; 61: 2s-41s.

[12] Mohler ER 3rd, Treat-Jacobson D, Reilly MP, et al. Utility and barriers to performance of the ankle-brachial index in primary care practice. Vasc Med. 2004; 9: 253-260.

[13] Verberk WJ, Kollias A, Stergiou GS. Automated oscillometric determination of the ankle-brachial index: a systematic review and meta-analysis. Hypertens Res. 2012; 35: 883-891.

[14] Herráiz-Adillo A, Cavero-Redondo I, Álvarez-Bueno C, et al. The accuracy of an oscillometric ankle-brachial index in the diagnosis of lower limb peripheral arterial disease: A systematic review and meta-analysis. Int J Clin Pract. 2017; 71: el2994. 
[15] Kolossvary E, Ferenci T, Kovats T, et al. Trends in major lower limb amputation related to peripheral arterial disease in Hungary: a nationwide study (2004-2012). Eur J Vasc Endovasc Surg. 2015; 50: 78-85.

[16] Clairotte C, Retout S, Potier L, et al. Automated ankle-brachial pressure index measurement by clinical staff for peripheral arterial disease diagnosis in nondiabetic and diabetic patients. Diabetes Care 2009; 32: 1231-1236.

[17] Herráiz-Adillo A, Martinez-Vizcaino V, Cavero-Redondo I, et al. Diagnostic accuracy study of an oscillometric ankle-brachial index in peripheral arterial disease: the influence of oscillometric errors and calcified legs. PLoS ONE 2016; 11: e0167408.

[18] Kollias A, Xilomenos A, Protogerou A, et al. Automated determination of the ankle-brachial index using an oscillometric blood pressure monitor: validation vs. Doppler measurement and cardiovascular risk factor profile. Hypertens Res. 2011; 34: 825830.

[19] Gómez-Huelgas R, Martínez-Gonzalez J, de Albornoz MC, et al. Automated ankle-brachial pressure index measurement by clinical staff for peripheral arterial disease diagnosis in nondiabetic and diabetic patients: response to Clairotte et al. Diabetes Care 2010; 33: e41.

[20] Bland JM, Altman DG. Statistical methods for assessing agreement between two methods of clinical measurement. Lancet 1986; 1: 307-310.
[21] Stergiou GS, Karpettas N, Atkins N, et al. European Society of Hypertension International Protocol for the validation of blood pressure monitors: a critical review of its application and rationale for revision. Blood Press Monit. 2010; 15: 39-48.

[22] Korno M, Eldrup N, Sillesen H. Comparison of ankle-brachial index measured by an automated oscillometric apparatus with that by standard Doppler technique in vascular patients. Eur J Vasc Endovasc Surg. 2009; 38: 610-615.

[23] Ransohoff DF, Feinstein AR. Problems of spectrum and bias in evaluating the efficacy of diagnostic tests. N Engl J Med. 1978; 299: 926-930.

[24] Diehm N, Dick F, Czuprin C, et al. Oscillometric measurement of ankle-brachial index in patients with suspected peripheral disease: comparison with Doppler method. Swiss Medical Weekly 2009; 139: 357-363.

[25] Wohlfahrt P, Ingrischova M, Krajcoviechova A, et al. A novel oscillometric device for peripheral arterial disease screening in everyday practice. The Czech-post MONICA study. Int Angiol. 2011; 30: 256-261.

(Járai Zoltán dr., Budapest, Tétényi út 12-16., 1115 e-mail: kardiologia@szentimrekorhaz.hu)

\section{A Magyar Endokrinológiai és Anyagcsere Társaság (MEAT) pályázatot hirdet a 2018. évi MEAT Ifjúsági Díjra}

Pályázati feltételek:

(1) A pályázó életkora a pályázat beadásakor nem haladhatja meg a 35 évet.

(2) Pályázni lehet a tárgyévben vagy az azt megelőző évben megjelent vagy közlésre elfogadott dolgozattal. Ha a pályázónak több közleménye is megfelel a pályázati feltételeknek, a pályázó választása szerinti egyetlen közleménnyel lehet pályázni.

(3) A pályázatra benyújtott dolgozat témájának az endokrinológia vagy a neuroendokrinológia tárgykörébe kell tartoznia.

(4) Hazai laboratóriumban készült és önállóan végzett munka előnyben részesül.

(5) Többszerzős munka esetén a pályázó a dolgozat első szerzője kell legyen.

(6) 2017-ben, vagy azt megelőzően létesített MEAT tagság, 2018-ig rendezett tagdíj

Az Ifjúsági Díjat évente egy pályázó nyerheti el, a Dij díszoklevélből és pénzjutalomból áll (150 000 forint). A dij odaítélésére a MEAT elnöke által felkért bíráló bizottság tesz javaslatot, a végleges döntést a MEAT vezetősége hozza meg.

A pályázat beküldési határideje: 2018. április 15 .

A nyertes pályázó dolgozatát a MEAT 2018. évi kongresszusán ismerteti.

A pályázatot a MEAT főtitkárához (Prof. Dr. Tóth Miklós, Semmelweis Egyetem, II. Belgyó-gyászati Klinika, toth.miklos@med.semmelweis-univ.hu) kell benyújtani (pályázat + megjelentelfogadott dolgozat elektronikus változata + szakmai önéletrajz). A pályázónak nyilatkoznia kell, hogy a társszerzőket előzetesen értesítette a dolgozat pályázatra történő benyújtásáról. 